Warm up

\section{Anyone for tennis?}

\section{P McCrory}

missed. Strangely, we seem to have a company called Waste Audit, who specialises in, you guessed it, counting waste material. According to them, tennis balls do not even rate as a litter item. What a relief! With the recent drought breaking rains, we may have been at high risk of tennis ball impaction resulting in blocked drains and flooding.

An illegal tennis ball export black market to third world countries hoping to emulate Australia's recent tennis prowess perchance. Maybe that is why they now $x$ ray all the bags on international flights. Forget the bombs, they are looking for 14 million missing tennis balls!

Allowing for a few balls eaten by errant dogs, there are still a lot of tennis balls unaccounted for. Perhaps a Royal Commission may help answer this question. Or a Tennis Ball Summit. Any suggestions should be sent to the Australian Prime Minister.

\title{
OBITUARY
}

Chris Brasher (d. age 74) and Sports Medicine

Chris Brasher, pacemaker for the first four minute mile, Olympic gold for the steeplechase in 1956, innovative sports journalist, BBC executive, founder of the London Marathon, successful mountain boot designer and sports shoe retailer, environmentalist, latterly race horse owner, and, above all, enthusiast. Brasher's recent death has revealed even to his friends new facets to a multi-talented man. This included an interest in sports medicine.

Brasher was a member of BASEM and was convinced that the non athlete could benefit from rising to a physical challenge, and founded the London Marathon on that basis. $\mathrm{He}$ recruited me as medical director, (provisional on certain conditions which he readily accepted). Brasher encouraged and supported and-when he could-attended the Marathon Medicine conferences I organised in association with the marathon, the biggest being the three day International Conference in 2000, to which he contributed and wrote the introduction to the subsequent book Marathon Medicine.

The involvement of the Greater London Council in the marathon led to the initiative, strongly supported by Chris, of setting up the London Sports Medicine Institute. After two years of negotiations which involved Chris Brasher, Peter Pitt, Emlyn Jones, Mary Glen-Haig, and myself, (who all served on the board of management) I left County Hall with a cheque for $£ 850000$ - a grant for five years. The LSMI was the first base for sports medicine in Britain with a library, laboratory, lecture courses, and meeting rooms. Its teaching courses contributed to the Apothecaries setting up their Diploma Exam in sports medicine, the first national examination in sports medicine. In 1992 it was taken over by the Sports Council as the NSMI, and has since moved from its base at Charterhouse Square, London.

Not everything Brasher touched turned to gold, but much did. He certainly had infectious enthusiasm, which would brook no opposition, and he will be greatly missed.

Dan Tunstall Pedoe

Medical Director, London Marathon and Medical Director, LSMI 1985-92 


\section{Expression of concern about content of which Dr Paul McCrory is a single author}

This paper is authored by Dr Paul McCrory. During 2021 and 2022 there was an investigation by BJSM and BMJ which found that some of his work was the product of publication misconduct. Such misconduct includes plagiarism, duplicate publication, misquotation and misrepresentation in publications in respect of which he was listed as the sole author. ${ }^{1}$ We are placing a notice to readers on all content in relation to which he is identified as the sole author to alert them to the conclusions of our investigation.

(C) Author(s) (or their employer(s)) 2022. No commercial re-use. See rights and permissions. Published by BMJ.

Br J Sports Med 2022;0:1. doi:10.1136/bjsports-2022-106408eoc

D) Check for updates

\section{REFERENCE}

1 Macdonald H, Ragavooloo S, Abbasi K. Update into the investigation of former BJSM editor-in-chief Paul McCrory. Br I Sports Med 2022. 